DR SCOTT MACWILLIAM is an academic with the State, Society and Governance in Melanesia Project at the Australian National University.

\section{A PNG media era when development mattered}

Press, Politics and People in Papua New Guinea 1950-1975, by Philip Cass. Auckland: Unitec e-Press, 2014, 205pp. ISBN 978-1-927214-09-1

$\mathcal{D}_{\text {should be required reading for }}^{\text {RESS, Politics and People }}$ people who are concerned with the history and current trajectory of Papua New Guinea. It is also a book with much to offer for university courses in journalism, history and social science methodology. Philip Cass shows in considerable detail how to research and write a detailed study about an important topic by employing a wide range of research methods, including interviews, content analysis of newspapers, analysing academic and popular literature, and engaging in archival searches. Significantly, he does not waste any time 'interrogating the Other', but
PRESS, POLIITICS AND PEOPLE in Papua New Guinea $1950-1975$ $\operatorname{lig}_{2} \cos$

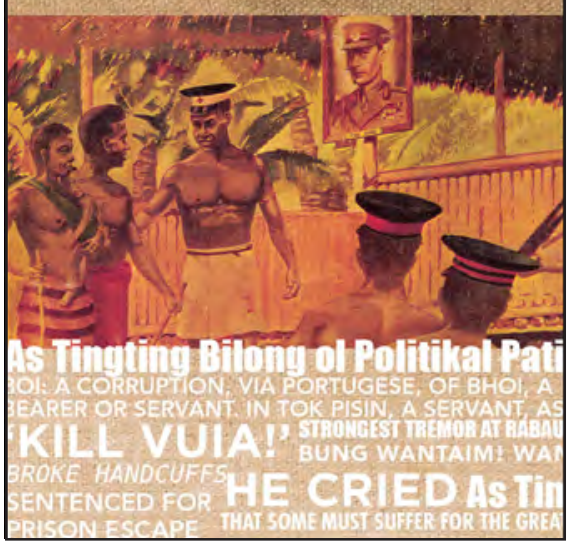

sustains several arguments about the place of the press during a critical moment when major change was in the air for the people of Papua New Guinea.

Cass has succeeded in turning a $\mathrm{PhD}$ thesis into a readable book, no mean feat in itself. The research and writing for the study occupied many years, and was carried out in PNG, the UK, the United Arab Emirates, France, Fiji, and Australia. No three to four-year instrumental doctorate upon which to base a superficial manuscript here. As the author cautiously states (p. 10) the purpose of the study is to describe and examine what occurred in PNG after World War II during the transition to Independence. The lens 
employed to view the changes is 'the commercial and church press-and, to a certain extent, official and mission publications'.

Cass employs the idea of developmental journalism, an adaptation of development information to support political development, which he borrows from the work of R. L. Stevenson to bring the lens into focus. This form of journalism is clearly nationalist in intent, with journalists bearers of news about the increasing scale of 'traditional' or 'tribal' societies in the drive for state formation and independence. The test for newspapers and those who own and produce them then becomes to what extent does the content of stories, letters to the editor and other contributions which appear, reflect as well as contribute towards nation-building? Indigenous nationalist political awareness and the increasing grip upon state power by indigenes becomes a central focus of developmental journalism.

Wisely, Cass does not pretend that his study is comprehensive: instead he employs a photographic image, 'a series of snapshots', to cover the main empirical material which is central to the study. Cass examines three newspapers in depth and only for specific periods, depending upon availability and in the case of one, The Rabaul Times, for its entire brief existence. The papers are The Rabaul Times (1957-59), the Post-Courier for September-December 1969 and the Tok Pisin Wantok (1970-75). 'The papers have been selected because of their importance to the development of the press in PNG and because of the issues they covered and what they represented' (p. 14).

This material is set out in eight chapters, arranged broadly into three parts. The first deals with broad historical changes in the development of the press in the Australian colony of Papua and the United Nations Trust Territory of New Guinea. In the second, chapters 3-5 Cass looks at specific issues and the coverage in particular papers of important and controversial events. Chapter 3 examines The Rabaul Times and the late 1950s eruptions over land and local government on the Gazelle Peninsula. Chapter 4 looks at the coverage in the Post-Courier of the political tensions and disputes which arose over the end of colonial rule and the passage to self-government in 1969, a year full of controversy and seminal moments. Cass emphasises that this view of what is important is heavily influenced by the paper's readership which is mainly expatriate, English-speaking, as also applied to The Rabaul Times a decade earlier. Chapter 5 also relies heavily on the 
Post-Courier to examine the Bougainville crisis as a revolt against the establishment of the Panguna mine and Arawa township, as well as another case of what has been termed micro-nationalism versus separatism.

Chapters 6-8 provide what is, in important respects, the heart of the book, dealing with the relationship between indigenous nationalism and the role of the press in forming national awareness. Here the main press expression of this formation is the establishment of a Tok Pisin newspaper Wantok. Cass argues that after WWII Tok Pisin gained standing as what he terms a lotu (church or mission) language through the inability of the colonial administration to make the international language English, the lingua franca of PNG. Without any lingua franca space was open for the creation of a standardised Tok Pisin, and Wantok, a newspaper established in 1970 by a Catholic priest, Fr Francis Mihalic, author of the most widely used Tok Pisin dictionary. It is in the analysis of Wantok's role that Cass shows where his heart lies, clearly with those who are attracted to nationalism, and also where he stands in the continuing debates about the priorities for literacy education in a country which has one of the lowest rates of literacy in the South Pacific and the world. This debate, which revolves around the ordering of Tok Ples, Tok Pisin and English/'globiesh' for literacy training, shows no sign of abating.

One of the difficulties or tensions which arises in this debate is whether there can be a lingua franca and an influential newspaper which is almost entirely in this language that survives commercially when literacy rates are so low. It is all very well to aim a paper at what Cass terms 'the grassruts', perhaps common people in English, but when due to poor education and insufficient related services the smallholders, unskilled, unemployed and similar strata at which the newspaper is directed are illiterate, who will buy the paper (as distinct from who will smoke it)? Cass points to this dilemma, acknowledging that when it was established Wantok was bought by what in PNG is a limited educated stratum who are also versed in English. Nevertheless as standards of education have failed to improve since Independence, and Wantok has limped from financial crisis to crisis, Cass and others maintain an enthusiasm for a Tok Pisin newspaper primarily on nationalist grounds. In the meantime not only are newspapers in trouble world-wide, but Papuan New Guineans have embraced international forms of communication. Most of these do not require proficiency in 
any written language while fluency in written and spoken English/'globiesh' is the principal passport for skilled and managerial employment, not 'grassruts' people.

Perhaps the most important message from Cass's well researched and written book is that the period he writes about was when newspapers were indeed important for developmental journalism. Now without development anywhere, perhaps it is unsurprising that the press and other media don't find this objective worthwhile either. Fortunately we have scholars, including Cass, to remind us when development was central to human affairs, including in Papua New Guinea as its people headed for Independence. This is a must read book with lots to learn from and argue about.

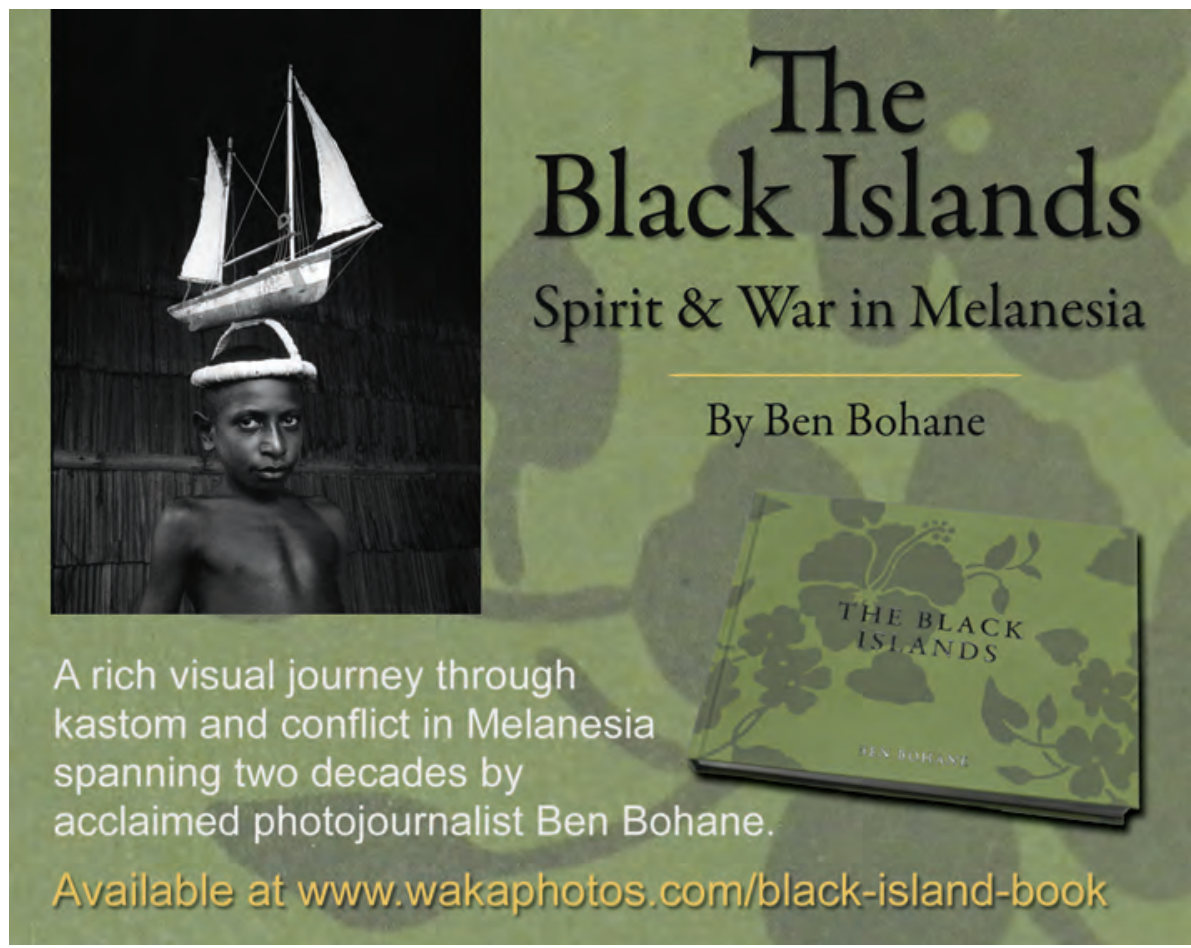

PACIFIC JOURNALISM REVIEW 20 (2) 2014251 